\title{
Luis Buñuel's Missing Dog and Other Animals: Un Chien andalou (1929), L'Âge d'or (1930) and Las Hurdes: Tierra sin pan (1933)*
}

\author{
JO EVANS \\ University College London
}

Tomo como tipo de film perfecto el cómico americano en donde el elemento humano no tiene preponderancia sobre el natural (Buñuel, 1929). ${ }^{1}$

\section{Introduction: Looking at Animals}

In 1929, Luis Buñuel expresses a preference for films in which the 'elemento humano no tiene preponderancia sobre el natural'. He reiterates this interest in a more equitable balance between human beings and their surroundings just over four decades later in conversation with Ivonne Baby. Here, Buñuel's concern is with the negative impact of the rising human population, which he regards as 'la principal responsable de todas las catástrofes modernas'. He notes that 'me apasiona la ecología, por eso tengo un gran sentimiento de ternura hacia la Naturaleza' and mentions Rachel Carson's book Silent Spring (1962). ${ }^{2}$ This establishes Buñel's interest in the work that inspired writers like John Berger, who would go on to inspire the academic 'animal turn' and the focus on the cinematic representation of

* This paper forms part of a three-year research project, Buñuel: A Life in Letters, generously funded by the Leverhulme Trust. Thanks are also due to Breixo Viejo, Sarah Wright and Lourdes Orozco for comments on an earlier draft of this paper.

1 Interview with Luis Gómez Mesa for Popular Film reprinted in Luis Buñuel: Vivo, por eso soy feliz, ed. \& intro. Jorge Gorostiza (Salamanca: Confluencias, 2015), 25-31 (p. 28; emphasis added). This comment is preceded by the lines: 'El cine me parece el representante más específico de nuestra época, nacido tan en función de sus necesidades espirituales, como la catedral en la Edad Media. Pero si esta supone dolor, el cine supone alegría'.

2 This interview with Ivonne Baby was first published in 1972 and reprinted as 'Luis Buñuel: me atraen las contradicciones de la burguesía', in Luis Buñuel: Vivo, por eso soy feliz, ed. Gorostiza, 111-20 (p. 118). 
nonhuman identities that has come to the fore at the turn of the twentyfirst century. ${ }^{3}$ As our negative ecological impact on the planet has become increasingly visible at the touch of a keyboard, cultural critics from Berger to Donna Haraway have urged us to scrutinize ourselves more closely in our nonhuman 'others', making this a particularly appropriate moment to take a closer look at animals in films directed by Buñel: the director who spent so much of the twentieth century making films in which animals are used to puncture our sense of our own 'preponderancia sobre el [elemento] natural', and fracture illusions we might harbour about the secure boundaries of the human-nonhuman divide. ${ }^{4}$

It is not surprising, given this interest in the natural world that animals should feature so highly in the thirty-two films Buñuel directed. ${ }^{5}$ Yet, while reference has been made to the insects, the goat sacrificed in Las Hurdes (1933) and the chickens, academic criticism has tended to focus on the way the human protagonists mediate dreams of Surrealist/Marxist utopia and Freudian fantasies of heterosexual desire in films where Fernando Rey so often enacts the frustrated Bunuelian alter ego or masculine 'other'. 6 More recently however, Julián Gutiérrez-Albilla's rereading of the Mexican and Spanish films has queered our approach to Buñuel's work in a way that offers fertile ground to ask what the more diverse 'others' and, for the purpose of this paper, what nonhuman others bring to this blackly ironic and caustically surreal oeuvre. ${ }^{7}$

The most famous animals associated with Buñel may be the severed calf's eye and the missing dog in Un Chien andalou (1929), but an extensive menagerie also appears in his work from the scorpions in L'Âge d'or to the zoo at the dénouement of Le Fantôme de la liberté (1974). Their function is

3 For an overview of the 'animal turn' in film studies, see the 'Introduction' to Laura McMahon's edited collection, Screen Animals Dossier, ed. Laura McMahon, Screen 56:1 (2015), 81-87. For John Berger's major contribution, 'Why Look at Animals?', see John Berger, About Looking (London: Bloomsbury, 2009 [1 $1^{\text {st }}$ ed. 1980]), 3-28, and for analysis of this essay, see Jonathan Burt, 'John Berger's "Why Look at Animals?”: A Close Reading', Worldviews: Global Religions, Culture, and Ecology, 9:2, (2005), 203-18.

4 See, for example, Jacques Derrida's 1997 lecture, 'The Animal That Therefore I Am (More to Follow)', trans. David Wills, Critical Inquiry, 28:2 (2002), 369-418; Donna Haraway, When Species Meet (Minneapolis/London: Univ. of Minnesota Press, 2008).

5 For a helpful summary of animals in films by Buñuel, see: 'El bestiario de Luis Buñuel' on Manuel Fructuoso's website En torno a Luis Buñuel, 13 November $2013<$ https://lbunuel.blogspot.co.uk/2013/11/el-bestiario-de-luis-bunuel-1.html> (accessed 2 January 2017).

6 For a recent example of work on the insects, see Paul Begin, 'Entomology As Anthropology in the Films of Luis Buñel', Screen, 48:4, (2007), 425-42.

7 Julián Daniel Gutiérrez-Albilla, Queering Buñuel: Sexual Dissidence and Psychoanalysis in His Mexican and Spanish Cinema (London: Tauris, 2008). 
not always obvious, nor is it limited to the visual, although that is the primary focus of this paper. The sound of animals is also important. Where Buñuel kept control over the sound track, animals noises-off tend to feature more often than extra-diegetic music, and for all the visual menagerie that is so vital to films like Belle de jour (1967)—-the cats, bulls, and horses-it is the sound of the mysteriously buzzing invisible insects in the box that so neatly sums up the sexual mysteries of this film. ${ }^{8}$

Figure 1

What is in the box?

Belle de jour $(1967)^{9}$

Insects in these films are often linked to the bizarre tangents taken by repressed human sexual desire. Buñuel describes as a 'scherzo' the ending of Ensayo de un crimen (1955), which includes another obscure humaninsect encounter directly linked to the odd permutations of human desire. In this case it is the shot of the protagonist-a frustrated serial murderer of women-poking at a grasshopper with his walking stick. ${ }^{10} \mathrm{He}$ appears to decide to let the creature live, throws the stick away, and walks off in a parody of heterosexual cinematic bliss with one of the women he had earlier intended to kill, Lavinia (Miroslava Sternova). This is a particularly enigmatic man-insect exchange. Elsewhere nonhuman animals are used more straightforwardly to highlight the apparently arbitrary obstruction of sexual desire: in Buñuel's last film, Cet obscur objet du désir (1977), barking dogs, a mousetrap and a fly in a drink signal the sexual frustration of Mateo/Mattieu (Fernando Rey).

8 Buñuel's self-avowed aversion to film music has been much discussed, although Breixo Viejo has queried whether we should take this at face value in 'La libertad de la imaginación: música y sonido en el cine de Luis Buñuel', in Luis Buñuel: Political Exile, Auteur, Iconoclast, ed. Jo Evans \& Breixo Viejo, BSS, XCIII:4 (2016), 639-56. For examples of Buñuel's negative comments about film music, see his conversation with Guillermo Cabrera Infante where he claims to detest film music because 'eso de utilizer música para subrayar un sentimiento me parece deleznable, muy poco legítimo' ('El elefante de Buñuel', in Luis Buñuel: Vivo, por eso soy feliz, ed. Gorostiza, 53-68 (p. 63).

${ }^{9}$ All images reproduced by kind permission of the heirs of Luis Buñuel.

10 Bunuel uses the word 'scherzo' with reference to the ending of Ensayo de un crimen in an interview with Cabrera Infante. He describes it as a 'final feliz arbitrario [...] tan absurdo como las situaciones trágicas anteriores' ('El elefante de Buñel', 65). 
Buñuel is also well known for his use of poultry. ${ }^{11}$ Cockerels, chickens and chicken feathers recur. One of the wealthy guests in El ángel exterminador (1962) keeps chicken feet in her opera bag and chickens are a recurrent foil to Pedro's picaresque journey in Los olvidados (1950). Floating feathers herald his famous dream sequence. He is described as a boy who loves chickens, but he will be driven to kill them, and when he breaks the fourth wall, he does so by throwing a chicken's egg at the camera. This shot draws abrupt attention to the fraught process of looking and looking back that is also so important to the writers we now associate with the animal turn. Buñuel's interest in challenging the boundaries of the human-animal gaze has been noted by Tom Conley. Conley points out that shots like the one in Un Chien andalou where Batcheff studies the ants swarming on his own hand blend the body/subject with the object of scientific scrutiny. ${ }^{12}$ And a similarly enigmatic approach to humannonhuman scrutiny can be found in other shots where human protagonists look at animals and/or vice versa.

The ending of Le Fantôme de la liberté includes a memorable close-up of an ostrich looking (apparently perplexedly) at the camera, and therefore out at the cinema audience. This shot brings the role of the viewer directly, and comically, into the question of human dominance in the field of the cinematic gaze. El bruto (1952) closes with another enigmatic example of human-nonhuman visual exchange. In this case the treacherous femme fatale, Paloma comes face-to-face with a cockerel immediately after urging police to kill her lover (the eponymous 'bruto') with the words: ' $E$ Es una bestia, mátale!'. She looks for an uncanny length of time at this cockerel before circling it and walking off. Here, the metaphorical associations with Christianity, crowing and betrayal are overt, yet the silence and length of the shot produce a sense of visual overload that complicates these more straightforward symbolic connotations. ${ }^{13}$ Geoffrey Kantaris examines this half-crazed gaze with reference to the effects of affect described in AntiOedipus by Gilles Deleuze and Félix Guattari as the 'power of the pack [that] throws the self into upheaval and makes it reel'. Kantaris extends this quotation from Deleuze and Guattari to include comments about

11 For a recent example, see Tom Conley, 'Buñuel Entomographer: From Las Hurdes to Robinson Crusoe', in A Companion to Luis Buñuel, ed. Rob Stone \& Julián Gutiérrez-Albilla (Chichester: Wiley-Blackwell, 2013), 188-202.

12 Conley, 'Buñuel Entomographer', 190-91.

13 Geoffrey Kantaris, 'The Cinematic Labor of Affect: Urbanity and Sentimental Education in El bruto and Ensayo de un crimen', in A Companion to Luis Buñuel, ed. Stone \& Gutiérrez-Albilla, 302-23 (p. 319).

13 The contribution of animals to the collapse of symbolism is one we shall return to with reference to Jonathan Burt, Animals in Film (London: Reaktion Books, 2002). 
human-animal 'becomings' that he then develops with specific reference to Buñuel. He quotes Deleuze and Guattari's point that:

Who has not known the violence of these animal sequences, which uproot one from humanity, if only for an instant, making one scrape at one's bread like a rodent or giving one the yellow eyes of a feline? A fearsome involution calling us toward unheard-of becomingness.

Then, having added this emphasis to their last line, Kantaris links this notion of 'monstrous becomings' to the way that Bunuel's work

[...] opens up a space in which the immense upheavals of urban modernization are played out very precisely in the interpersonal flows of affect [...] and, above all in its distillation in the affective machinery of cinema itself. ${ }^{14}$

This astute analysis of the self-reflexive impact of an oddly long shot of a woman looking at a cockerel highlights the medium of cinema in a way that nicely corresponds with the comment from Buñel in 1929 that was used to open this paper about films, "donde el elemento humano no tiene preponderancia sobre el natural'. For Kantaris, the combined 'power of the pack' (of ideology, affect and film itself) constructs the kind of 'monstrous becoming' that is implied in Paloma's fixed stare. And a shot drawing similarly obscure attention to the cinematic framing of affect and 'monstrous becomings' can be found in Los olvidados. In this case, though, it is an even more enigmatic shot of a blind man looking at a chicken.

Whereas the link with Christian myth is clear (if exaggerated) in the shot of Paloma looking at the cockerel, the significance of this visual exchange is left diegetically and symbolically opaque. It occurs just after the blind man has been attacked by the eponymous gang of boys, so it links the man who cannot see to the boys, and to the chickens that act as a foil to Pedro. It is also not irrelevant that this same man will shout out that he wishes they ('los olvidados') were all dead at the end of the film. Yet among these potential connotations, it is the fact that the man is blind that raises the most interesting question about what we are looking at and how this shot might queer the issue of human 'preponderancia' in the field of the gaze: is this a man looking at a chicken, or a chicken looking at a man? ${ }^{15}$

Buñuel came of age alongside writers like Jean-Paul Sartre and Jacques Lacan, whose work has had a major impact on the way we perceive ourselves in the eyes of our beholders, and this succinct visual gag (in which a chicken looks at a blind man) raises issues that, for Buñel as for

14 Kantaris, 'The Cinematic Labor of Affect', 320.

15 This question resonates, of course, with Derrida's investigation into exchanged gazes in 'The Animal That Therefore I Am' (1997), and with Berger's 1977 essay 'Why Look at Animals'. 
Derrida and Donna Haraway, are often expressed most directly through humour. For our 'others', after all, are not simply external beings we observe, but protagonists of our unconscious to which jokes and visual gags may be our only available access. If Buñuel uses a shot of a blind man and a chicken to provide a way in, Derrida uses linguistic puns (for example, his witty substitution of the word 'animal' with 'animot') and Haraway uses a New Yorker cartoon about wolves. ${ }^{16}$ This cartoon relies for its humour on the substitution of the phrase 'raised by scientists' for the phrase 'raised by wolves' to introduce her work questioning our assumptions about visual exchange, species' identity, and the 'ontics and antics of significant otherness'. 17

Unlike Haraway, whose book expands lucidly and at length on the implications of this joke, Buñuel is content to offer a series of unexplained images: of a cockerel and a woman; a chicken and a blind man; or an ostrich that mirrors the viewing audience back at itself. However, his preference for films that diminish the element of human "preponderancia sobre el [elemento] natural' suggests that he shares with Haraway an interest in levelling the human-animal gaze. For this reason, it is worth expanding briefly here on the link Haraway makes between the process of 'looking back' and the semantic relationship that exists between the words 'respect' and 'looking'. She points out that: 'respect is respecere-looking back, holding in regard'18 and that:

Even when we speak only of people, the animal/human/living/non-living category separations fray inside the kind of encountering worthy of regard. The ethical regard that I am trying to speak and write can be experienced across many sorts of species differences. The lovely part is that we can know only by looking and by looking back. Respecere. ${ }^{19}$

While Buñuel would not have admitted to any such clear ethical motivation for his own visual evocation of our close encounters with our animal others, his work shares with Haraway's an interest in combining humour with the motif of looking back to 'fray' the edges of the animal-human divide.

\section{Buñuel's Menagerie: Levelling the Human-Nonhuman Gaze}

16 See Derrida, 'The Animal That Therefore I Am', trans. Wills, 416, and Haraway, When Species Meet, 13. The cartoon relies for its humour on substituting the phrase 'raised by scientists' for 'raised by wolves'; see $<$ http://www.condenaststore.com/-sp/We-found-her-wandering-at-the-edge-of-theforest-She-was-raised-by-scien-New-Yorker-Cartoon-Prints_i8541873_.htm> (accessed 12 January 2017).

17 Haraway, When Species Meet, 164.

18 Haraway, When Species Meet, 88.

19 Haraway, When Species Meet, 164. 
In order to 'fray' these edges, humans and nonhuman protagonists need to be in close contact, and while the human protagonists of films focusing on rural and urban poverty, such as Las Hurdes (1932) and Los olvidados, live naturally in close contact with animals, this is also true of many of the protagonists of the less socially motivated, more commercial films including: Susana (1950); El bruto (1952); Robinson Crusoe (1953); Abismos de pasión (1954); El río y la muerte (1954) Cela s'appelle l'aurore (1955); La mort en ce jardin (1956); La fièvre monte à El Pao (1959); and The Young One (1960).

Although Buñuel rejects the notion that his films contain symbols, these animals clearly represent something and the tethered deer in The Young One may be the exception that proves this rule. ${ }^{20}$ This deer comes as something of a shock in a film directed by Buñel, because its function is to highlight the sexual abuse of the innocent 'young one' and the racial abuse of the falsely accused jazz player, and its appearance is so overtly symbolic that it is safe to regard it as visually and virtually unique in Buñel's work. Other overt symbols of innocence do appear-for example, the white dog kicked by the protagonist in L'Âge d'or, and the white sheep kicked by the devil in Simón del desierto (1965)—but they are framed with a much more familiar irony that nudges the symbolic role they play in the representation of innocence versus human misdemeanours towards farce. The devilish sheep-carrying temptress in Simón del desierto leads us to the link between animals, the human sex drive and religion that is recurrently emphasized in these films. Animals appear in numerous visual and verbal jokes about human sexuality. The melodrama, Susana, for example, emphasizes more often than is strictly necessary that the patriarchal ranch owner (who will be seduced by Susana along with his son and main ranch hand) really has eyes only for his horse, Lozana. In Cela s'appelle l'aurore, when the unhappily married doctor (Georges Marchal) finally consummates his shared passion for the nurse (María Bosé), our view is 'veiled' by a surreal cutaway to a shot of a hand placing a small tortoise on the ground upside down. ${ }^{21}$ In Tristana (1970), mise-en-scène and editing also place the viewer's gaze and an animal at a comically low level, when Don Lope removes his

20 Raymond Durgnat discusses Buñuel's aversion to symbolic interpretations in a section on recurring motifs, where he reminds us that Buñuel claims some of more obscurely surreal moments in his films (such as the discussion of an eagle flying below an improvised toilet in El angel extermindor) are based on childhood memories (Raymond Durgnat, Luis Buñuel [London: Studio Vista, 1968], 46).

21 There is a much more sinister link between human sexual activity and animals elsewhere in Cela s'appelle l'aurore: the lovers meet when they attend a girl who has been abused by her grandfather and the culprit will be discovered hiding in the animal pens with the chickens. Viridiana makes more humorous reference to the sexual abuse of power, in this case Jorge's abuse of Ramona, with the shot of the cat catching a mouse in the attic. 
dog (and with the dog our view of events), from the bedroom where he is about to seduce his ward.

Ironically, given that this is a factual rather than fictional example of human-animal interaction, the most perverse image linking nonhuman animals with human sexuality is perhaps the one involving the cockerels in Las Hurdes. This is the documentary footage of a traditional ceremony in the more wealthy village of La Alberca during which recently married men must attempt, on horseback, to pull the head off a live cockerel hanging upside down over the street. In this case, the lugubrious narrative voiceover contributes the ironic overload that is so characteristic of Buñel: 'Each man must rip off a head. The bloody ritual is undoubtedly an obscure reference to various sexual symbols or complexes that it is not our task to analyse now'. ${ }^{22}$ This ironic nod to the link between the symbolic castration of the cockerels and human weddings makes it clear that despite his professed antipathy to symbols-Buñel was well aware that any form of representation, and particularly of the oneiric and surreal kind he prefers, will trigger conscious and unconscious associations in the mind of the viewer (that it may, or may not be 'our task to analyse now'). ${ }^{23}$ The way that this narrative joke so neatly disavows (that is to say, the way it draws a veil over whilst simultaneously alluding to) the full Freudian implications of the link between pulling off cockerel heads and heterosexual marriage could well stand as a metonym for the many other obscure references to 'sexual symbols or complexes' involving animals that are left so comically unexplained in Buñuel's work.

If animals in Buñuel's films are associated with our appetite for sex, they are also, logically enough, associated with our desire to eat. Buñuel's protagonists' dreams often conflate food and sex with those animals that form part of the human food chain. ${ }^{24}$ Animals alive and dead star in his protagonists' dreams. In Los olvidados, Pedro's dream sequence features his mother holding a lump of uncooked meat. Sheep multiply on a bus in

22 This version of the script in English appears in the collection of essays, Luis Buñuel et al., Reverse Angle, Cinema and Anthropology, ed. Andy Davies \& Núria Rodríguez (Madrid: Caja Madrid, 2007), 14-27 (p. 15).

23 Buñuel's antipathy is reserved for symbols used in an overly overt and therefore manipulative way. See his comment 'yo nunca he empleado símbolos adrede' and the distinction he makes between images and symbols in interview with Ivonne Baby ('Luis Buñuel: me atraen las contradicciones de la burguesía', 112-13).

24 Guy H. Wood and Javier Herrera Navarro discuss Buñuel's passion for guns and hunting in 'Buñuel, Master Pyrotechnician: The Roles of Firearms in His Cinema', in A Companion to Luis Buñuel, ed. Stone \& Gutiérrez-Albilla, 98-115. They make the point that 'like most cynegetic aficionados, Buñuel not only realized that to hunt is to be human but that nature is based on what Paul Shepard calls "the paradox of death as a source of life" ' (100). 
Subida al cielo (1951), and the endlessly deferred meal in Le Charme discret de la bourgoisie (1972) moves seamlessly from (surreal) diegetic reality to an increasingly complex system of dreams-within-dreams. This food-obsessed narrative concludes with a domestic military coup during which the Ambassador of Miranda (Fernando Rey) reaches up to steal some meat from the table under which he is hiding. He then wakes, abruptly, as he is about to be assassinated along with the rest of his dinner companions.

Religion, sex, social mores and eating animals are a recurrent source of black humour for Buñuel, who claims to have been vegetarian from the ages of eighteen to twenty. ${ }^{25}$ Slaughterhouses feature in La ilusión viaja en tranvía (1953) and El bruto: as a source of comedy in the first (the pig's head on the tram) and as a symbol of social oppression in the second (it is where the sacrificial protagonist, 'el bruto', works). Our relationship to eating meat is also, of course, vital to the films that mock the bourgeoisie. Used to particuarly surreal effect in the frustrated search for a meal in $L e$ Charme discret de la bourgeoisie, animals and eating also features in films like El ángel exterminador and Le Fantôme de la liberté. In El ángel exterminador an early image of an ice swan prepared to impress the postopera guests contrasts sharply with the sheep they will be reduced to scavenging, and Le Fantôme de la liberté features the dining room/bathroom reverse scenario, where guests sit around a table chatting over their 'toilette', but retire discreetly to eat a chicken leg.

Eating meat is linked to bourgeois pretension, political corruption, sexual appetite, territorial greed, and, of course, to the Catholic ritual of consuming the Host/body of Christ. An ironic connection between human (sexual) appetite and religion is made verbally in Él (1953). Here, a priest at a dinner party dodges a question about his views on love with the words: 'Que yo opino sobre el amor, que este pavo está muy bueno'. And a similar link between human opinion, religion and food is made in one of the bizarre discussions about religious doctrine and heresy in La Voie lactée (1969). In this case an innkeeper explains with concise if sacrilegious lucidity that: 'Christ is in the Host, like the hare is in this pâté. It's hare, and at the same time it's pâté'.

This brief summary of arresting animal images in films directed by Buñuel confirms that they are rarely as obvious, in symbolic terms, as the deer in The Young One and that their appearance is more often designed to

25 Ado Kyrou, Luis Buñuel: An Introduction, trans. Adrienne Foulke (New York: Simon and Schuster, 1963), 15. María Soledad Fernández Utrera links vegetarianism, along with naturism and reading Russian literature, to the 'señas de un estilo de vida ácrata por aquella época' in Buñuel en Toledo: arte público, acción cultural y vanguardia (Woodbridge, UK \& Rochester, USA: Tamesis, 2016), 88. 
overload and obscure their symbolic connotations in a way that is not unlike the effect of animals on screen that Burt describes as follows:

Although the animal on screen can be burdened with multiple metaphorical significances, giving it an ambiguous status that derives from what might be described as a kind of semantic overload, the animal is also marked as a site where these symbolic associations collapse into each other. ${ }^{26}$

In Buñuel's work the framing of animals tends to start at this point of 'symbolic [...] collapse'. From the earliest films - to which we now turnanimal images contribute to what Burt describes here as a point of 'semantic overload'. They are introduced deliberately to highlight points of rupture within the field of the gaze and play a vital role in in what Susan Cooper neatly summarizes as the intention of Surrealism, and Un Chien andalou in particular, to 'breach subjectivity'. ${ }^{27}$

\title{
Un Chien andalou: Animals, 'Monstrous Becomings' and Oedipal Transitions
}

\section{<INSERT EVANS FIGURE 7 ABOVE THIS CAPTION>}

\author{
Figure 7 \\ Severed calf's eye \\ Un Chien andalou (1929) \\ Reproduced by courtesy of the Madrid Filmoteca
}

The rupturing effect of the infamous image of the calf's eye in Un Chien andalou is not caused by the fact that we see it as an animal image of course: editing ensures we see it as human, and more specifically, as a female eye. Yet, its value as a metonym for visual rupture in Buñel's work links it usefully to Burt's point that 'the animal image is a form of rupture

26 Burt, Animals in Film, 11. See also his point that '[a]nimal imagery has a rupturing effect, both in terms of the way it unavoidably points beyond itself to wider issues and in its capacity to resist or problematize its own meanings on screen' (13).

27 Susan Cooper, 'Surreal Souls: Un Chien andalou and Early French Film Theory', in A Companion, ed. Stone \& Gutiérrez-Albilla, 141-55 (p. 142). For a recent detailed study, see Elza Adamowicz, Un Chien andalou (London: I. B. Tauris, 2010); Chapter 3 provides a very useful account of contemporary influences on Buñuel and Dalí (with reference to wider surrealist interest in the motif of the eye) and of the numerous intertextual references in the film (see pp. 63-90). 
in the field of representation'. ${ }^{28}$ This shocking blend (through editing) of the animal and human gaze also brings us back to the simile Deleuze and Guattari use in their description of affect as something that makes us 'scrape at one's bread like a rodent' or 'take on the yellow eyes of a feline'. It is a simile that separates the human from the nonhuman more dramatically than Buñuel's work tends to: his animal imagery more usually implies that such divisions are less dramatic than we like to think, and that our relationship to the 'pack' and 'monstrous becomings' is the stuff of daily farce that is so clearly addressed in Un Chien andalou, with its arresting images of the severed eye, its ants, dead donkeys and sea urchin.

The cinematic machinery that ensures we see this eye as human is echoed in the appearance of Buñel himself as the violent patriarchal pathologist of this animal/female gaze. It is an image that continues to deliver a memorable assault on the viewer and, symbolically, on the history of visual art and the potential for violence that lies at the heart of patriarchal ideology.

\title{
<INSERT EVANS FIGURE 8 ABOVE THIS CAPTION>
}

\author{
Figure 8 \\ Monstrous becomings of the Oedipal kind \\ Un Chien andalou (1929) \\ Reproduced by courtesy of the Madrid Filmoteca
}

Yet, although the implied victim of this cold-blooded incision is the female protagonist, it is her would-be seducer who exhibits the most extravagant symptoms of 'monstrous becomings' related to patriarchal, ideological and mediatic control. It is he, not she, who drools and howls silently at the moon as if he has introjected the missing eponymous $\operatorname{dog} .{ }^{29}$ The appearance of the

28 Burt, Animals in Film, 11. Burt's point is that '[a]nimal imagery in film has a peculiar status in that, despite a general awareness of the contrivances of the medium, audiences often respond differently to animals or animal-related practices than they do to other forms of imagery' (10).

29 This man-dog transformation is highlighted by the addition of the soundtrack by Argentinian composer Mauricio Kagel in the version re-released in 1983 for Swiss television. This uses the sounds of barking dogs to accentuate, comically, the frustration involved in this sexual encounter between the man and his reluctant female mate. 
punitive parental double then suggests, without confirming, that this is a fundamentally Oedipal human/nonhuman transformation.

Sexual frustration and patriarchal control are central to the representation of the 'dog-man' in this film. The ants that swarm from the stigma in the his right hand just over five minutes into the film are related, through a sequence of edited shots and dissolves, to the armpit of a female sunbather and a sea urchin, the circular shape of the sea urchin is then echoed visually in the circular overhead iris shot of the ethereal androgynous figure, who is poking his/her stick at a severed hand lying in the street below the flat where the male and female protagonists act out this bizarre sexual encounter. ${ }^{30}$

Federico García Lorca famously claimed that 'el perro andaluz soy yo', and given the closeness of his relationship with Buñuel and Salvador Dalí and their estrangement at this point, it is not difficult to see why he came to this conclusion. ${ }^{31}$ It is the male protagonist who responds sexually to the androgyne and the severed hand and then, with even greater fervour, when $\mathrm{s} /$ he is run over, clutching to his/her chest the unexplained stripy box. This association of sexual desire with castration, death and metamorphosis has parallels with the lyrical speech Lorca was writing for 'Pámpano' and 'Cascabeles' in El público at around the same time (1929-1930) although the tone differs radically. In Lorca's play, human to nonhuman metamorphosis celebrates the complexity of (homosexual) desire, while the theme of human to nonhuman metamorphosis in Un Chien andalou exposes the perverse symptoms of repressed sexual desire. This point is made most forcefully, of course, in the sequence where the male protagonist is hampered in his pursuit of the woman by the ropes that join his body to the grand pianos, the Marist priests and the dead donkeys.

Buñuel and Dalí's state of mind around this time is illustrated in the letter Buñuel wrote to José Bello on 10 February 1929. This includes a transcript of the letter Buñuel claims he and Dalí sent to Juan Ramón Jiménez. This version reads as follows:

30 The 2003 version restored by the Filmoteca Española is available at: $<$ http://www.rtve.es/alacarta/videos/un-perro-andaluz/perro-andaluz/1570997/> (accessed 9 January 2017).

31 Ian Gibson has examined this friendship in the closest detail. See Ian Gibson, Luis Buñuel: La forja de un cineasta universal, 1900-1938 (Madrid: Aguilar, 2013), and for one of his more recent accounts of Buñuel's views on the relationship between the film and Lorca, see this broadcast: 'Ian Gibson: "Buñuel se fue a la tumba pensando en el fusilamiento de Lorca" ', from RTVE, 28 April 2015. <http://www.rtve.es/noticias/20150428/ian-gibson-bunuel-se-fue-tumbapensando-fusilamiento-lorca/1135946.shtml> (accessed 8 January 2017). 
Nuestro distinguido amigo: Nos creemos en el deber de decirle-sí, desinteresadamente-que su obra nos repugna profundamente por inmoral, por histérica, por arbitraria.

Especialmente: ¡iMERDE!! para su Platero y yo, para su fácil y malintencionado Platero y yo, el burro menos burro, el burro más odioso con que nos hemos tropezado.

Sinceramente,

Luis Buñuel y Salvador Dalín ${ }^{32}$

The gleeful venom they reserve for Jiménez's fictional donkey in this shared Oedipal rush to the head adds a level of connotation to the dead donkeys in Un Chien andalou. ${ }^{33}$ The goading of a revered older writer is a minor detail in Buñuel's life, and it is unremarkable in Oedipal terms. However, it does help to accentuate the link between 'putrid' art and the 'putrid' donkey. It clarifies both the more straightforward Oedipal connotations of the dead donkeys, and the wider challenge that the animals in Bunuel's work present to the cultural status quo that we shall return to with reference to the cow in L'Âge d'or below. In Un Chien andalou, this Oedipal attack on the status quo is complicated by the film's final morbid image of 'frayed' human/nonhuman subjectivity. The two, now blind, protagonists are buried to their waists in sand and besieged by insects. ${ }^{34}$ This is a deliberately ambivalent dénouement that links back to the violence of patriarchal control implied in the shots where Buñuel takes his cutthroat razor to the calf's eye. Elusive though it remains, the editing of the human-nonhuman animal imagery in this film is clearly linked to human sexuality and patriarchal repression; to the psycho-sexual structure of the family; and to the issue of the cinematic gaze and cultural stultification to which Bunuel will return, with more obvious political intent, in L'Âge d'or.

\section{L'Âge d'or (1930): 'La Bête andalouse'}

\section{<INSERT EVANS FIGURE 9 ABOVE THIS CAPTION>}

32 Agustín Sánchez Vidal, Buñuel, Lorca, Dalí: el enigma sin fin (Barcelona: Planeta, 1988), 189.

33 Sánchez Vidal also mentions this letter in relation to Dalís 1930 essay, 'L'Âne Pourri' in his chapter 'L'Âge d'or,' in A Companion to Luis Buñuel, ed. Stone \& Gutiérrez-Albilla, 173-87 (p. 177).

34 For a detailed analysis of this sequence, see James Ramey, 'Baroque Buñuel: The Hidden Culteranismo in Un Chien andalou', in Luis Buñuel: Political Exile, Auteur, Iconoclast, ed. Jo Evans \& Breixo Viejo, BSS, XCIII:4 (2016), 575-60. 


\author{
Figure 9 \\ Sacred cow? \\ L'Âge d'or (1930) \\ Reproduced by courtesy of the Madrid Filmoteca
}

Provisionally entitled La Bête andalouse in homage to the Andalusian dog, this film includes numerous politically and culturally motivated animal gags, including the one with the large cow that will be the central focus of this section. ${ }^{35}$ Before turning to the cow however, it is worth summarizing briefly the numerous animal gags that appear in this film. The first is famously provided by the documentary found-footage of the scorpions that has been widely discussed for its links with both the film narrative and the political focus on the rise of Fascism. ${ }^{36}$ Anat Pick links early documentary footage of animals fighting to the Italian fascist representation of life as an on-going struggle, and it is typical of Buñel that he co-opts this same genre to mount a parodic attack on the 'Mallorcans', or Spanish supporters of Mussolini. ${ }^{37}$

The scorpion sequence ends with an intertitle, 'Quelques heures après', that provides a flimsy bridge to the band of outlaws (who include members of the Surrealist group). Their eerie dialogue mentions the mallorcans and their own accordions, hippopotami and mountain goats. This places incongruous animals at the heart of surrealist political protest, while the bandits' torpor (stung by scorpions?) suggests their hippopotami and

35 Sánchez Vidal notes that '[o]riginally, it was to going to be called La Bête andalouse (An Andalusian Beast), a title that was probably based on Henry Miller's suggestion to Buñuel in a lengthy letter, where he stated his endless admiration for the debut short film, even though he would have preferred the title Une chienne andalouse' ('L'Âge d'or', 172).

36 See, for example, Durgnat, Luis Buñuel, 38: 'The film itself is a scorpion, having five articulations (episodes) in the last of which the venom is concealed'. For a detailed and more recent account of the making, and reception of L'Âge d'or, see Sánchez Vidal, 'L'Âge d'or', 186, in which he notes that 'Godard projected it along with Battleship Potemkin (1925) as a supreme example of political cinema'.

37 See Anat Pick, 'Yervant Gianikian and Angela Ricci Lucchi's Animali Criminali', in Screen Animals Dossier, ed. McMahon, 95-101 (p. 96). 
mountain goats will be no match for the aggressive, speedy scorpions/supporters of fascism. This absurdist link between animals and human conflict is then extended in a subsequent sequence when the protagonist (detained for having sex with a woman in a public place) escapes his captors momentarily in order to kick a cute white fluffy dog gratuitously. ${ }^{38}$ Later, at around forty-three minutes in, the lovers are reunited in the garden of a mansion. ${ }^{39}$ This time their coupling is accompanied by the exaggerated sound of birds tweeting as the woman takes the man's hand in her mouth in an extended pastiche of fellatio and non-penetrative sex that concludes with the much discussed comment that she is glad they have assassinated their children. Animal imagery is deliberately used here, firstly to provide a parodic link with the rise of Fascism, and secondly to mock the social and religious frustration of human sexual desire: Catholic views on abstinence and contraception are surely the source of the parodic link made here between non-penetrative sex and the massacre of innocents.

The most comical animal in this film, however, is the cow that appears around twenty-five minutes in. The wealthy female lover enters her bedroom to find a large cow lying on her bed. She shoos it off as if it were no bigger, nor more remarkable than a pet dog or cat, and the cow lumbers offscreen. The noise of a cow-bell heard off is then joined by the sound of dogs barking at her lover who has been taken prisoner. ${ }^{40}$ Ado Kyrou's view of this sequence merits full consideration, for the questions it raises about Buñuel's aesthetic intentions. For Kyrou, this sequence is a vital prelude to the sequence he describes as:

The most perfect meeting of cinema and surrealism is the mirror sequence, which I think is the most magnificently poetic sequence in the history of the film. When Lya Lys enters her bedroom and finds a cow on her bed, the animal's bell becomes the predominant sound, a sound that persists even after the cow disappears. In the next frame, we find

38 A minute later, the same prisoner stamps on a beetle to the exaggerated sound of its body squashing, later, a different man will kick a violin along the street with similarly gratuitous disdain.

39 The mansion is associated with another gratuitous animal cameo involving the large grey horse that pulls a cart through a room now filled with the wealthy family and friends of the female lover. The guests (like the blasé guests in El ángel exterminador) are not the least put out: nor are they particularly disturbed by the shooting and death, outside, of a young boy. They are shocked, however, when the male protagonist/prisoner slaps his lover's mother in the face for spilling sherry over him. At this affront to bourgeois morality and human adult subjectivity, the guests gather round to commiserate and the man (the same 'prisoner' of desire of the opening) is led away once more, this time dragging along the floor the dress worn by the female object of his desire.

40 See also Sánchez Vidal's discussion of this sequence ('L'Âge d'or', 179). 
Gaston Modot with the police, but the sound of the bell still persists, with the barking of dogs superimposed on it. As soon as we return to Lya Lys, who is leaning over her mirror, which reflects a sky with drifting clouds, the dual sound of bell and barking is enriched by the sound of the wind. This triple sound accompanies the lovers during the entire sequence, although they are miles apart. The two sounds-bell and barking-inform the spectator immediately that he is witnessing the union of two people whom distance does not separate. The wind hails the triumph of their union. ${ }^{41}$

The cow-on-the-bed gag is surreal enough to withstand many conflicting interpretations of its relationship to this sequence, and I should like to add to Kyrou's evocative response a rather more prosaic reading of this attack on the cultural status quo. To do so, we need to look a little more closely the visual impact of this large (sacred?) cow and make some speculative links between the cow, the female protagonist and the French film avant-garde.

Germaine Dulac, the advocate of 'pure' cinema whose work is associated both with Impressionism and Surrealism was famously denounced as a 'vache' by Antonin Artaud at the premiere of the film she directed based on his screenplay La Coquille et le clergyman (1928). ${ }^{42}$ This spat appears to have been the result of a creative clash between his interest in 'a film of pure images' and Dulac's interest in using film to capture 'l'invisible humain'. ${ }^{43}$ Buñuel would have been well aware of this act of surrealist public affray in relation to Dulac, and if we add to this knowledge the trouble he took to find a suitably 'bovine' female lead for this film, it seems likely that the 'dreamy' mirror sequence that Kyrou so admires was, in fact, a conscious parody of a similar sequence involving a male lover, clouds and a sexually frustrated female protagonist (without the mirror and the

41 Ado Kyrou, Luis Buñuel..., 27. Elsewhere, Durgnat points out (via Brunius) that the word 'vache' is slang for 'cops'. He concludes that 'the cow suggests both the police, who are arresting the hero, and her mother', Luis Buñuel, 41.

42 Cooper notes that La Coquille et le Clergyman is now accepted as the first surrealist film, in spite of Dulac's 'dual status as an Impressionist and surrealist' and the fact that the Impressionists were openly mocked by the Surrealists, 'Surreal Souls', in A Companion, ed. Stone and Gutiérrez-Albilla, 141-55 (p. 142). For a detailed account of the 'Dulac, c'est une vache' debacle see Alain and Odette Virmaux, Antonin Artaud/Germaine Dulac, La Coquille et le Clergyman/The Seashell and the Clergyman: An Attempt to Shed Light on a Mythic Incident, trans. Dominique Virmaux and Tami Williams (Paris: Editions Paris Expérimental, 2009). Dulac and Cocteau can both be found on the 'Don't See' side of the two columns of films worth seeing, and films not worth seeing, in 'Some Surrealist Advice' (1951), reprinted in Paul Hammond, The Shadow and its Shadow: Surrealist Writings on the Cinema (Edinburgh: Polygon, 1991), 46-47.

43 See Sandy Flitterman-Lewis, To Desire Differently: Feminism and the French cinema (Urbana: Univ. of Illinois Press, 1996), 63. 
additional animal noises off) twenty-two minutes in to Dulac's 1927 film adaptation of Charles Baudelaire's L'Invitation au voyage. ${ }^{44}$ The beauty of the semantic overload in this sequence involving the cow is that it is entirely possible to read this sequence both as 'the most magnificently poetic sequence in the history of the film' and as a parody of Dulac's poetic cinema. It is typical of Buñuel's animal imagery in general, and of this cow in particular, that it suggests a range of paradoxical connotations that remain, none the less, closely tied to the issues of social, political and cultural hypocrisy to which Buñuel would return time and again in his work, and perhaps nowhere with more ferocity than in Las Hurdes.

\section{Las Hurdes: Tierra sin pan (1933): Sacrificial Economies and Life- Death Symbiosis}

The film that most consistently reflects Buñuel's on-going interest in the human relationship to the natural world is the first one he directed without contribution from Dalí, Las Hurdes: Tierra sin pan. ${ }^{45}$

\section{<INSERT EVANS FIGURE 13 ABOVE THIS CAPTION>}

44 For discussion of this search for a suitably bovine actress see Paul Hammond, 'L'Âge d'or', British Film Institute Film Classics, 2 vols, ed. Edward Buscombe and Rob White (London and New York: British Film Institute, 2003), 1, $115-37$ (p. 120).

45 For a detailed introduction to this film, see Mercè Ibarz, Buñuel documental: 'Tierra sin pan' y su tiempo (Zaragoza: Prensas Universitarias de Zaragoza, 1999); Javier Herrera, Estudios sobre 'Las Hurdes' de Buñuel: evidencia fílmica, estética y recepción (Sevilla: Renacimiento, 2006); and Jordana Mendelson, 'Centennial Revisions: Luis Buñuel's Las Hurdes: Tierra sin pan', Journal of Spanish Cultural Studies, 1:2 (2000), 215-23. 
Of these three early films, this is the one where the relationship between human and nonhuman identity is represented at its most literal level, as this surreal ethnographic narrative is both parodic and, at the same time, a serious denunciation of rural poverty. ${ }^{46}$ Here, the shooting of a goat, and the sequence where bees attack a dead donkey that is then scavenged by a dog exemplify McMahon's definition of the 'sacrificial economy of the animal, initiated by early documentary cinema'. ${ }^{47}$ This is a sacrificial economy has nothing to do with animal rights and everything to do with exposing the human symptoms of the kind of political corruption Bunuel had begun to explore in in L'Âge d'or. ${ }^{48}$ Although while contemporary film analysis links the representation of animals on screen to their vanishing from modernity, it is the absence of modernity that is emphasized in this brutally intimate on-screen portrayal of humans and their nonhuman counterparts. ${ }^{49}$

In this surreal documentary, the distinction between the diegetic and extra-diegetic that is so often highlighted by the use of animals is already blurred by the sometimes unbearably close attention this film narrative

46 When asked by Cabrera Infante about the relationship between Las Hurdes and Surrealism Buñuel reminds him that Surrealism 'para mí se trata de una forma de ver la vida, de vivir' and that 'denunciar la miseria era un postulado surrealista' (('El elefante de Buñul', 59). See also Reinaldo A Uribe Muriel's succinct blog entry on this blend of parody and social commentary with reference to Kuleshov and Imaginary Geography', http://provinciana.typepad.com/alma_provinciana/2007/04/imaginary_geogr.html (accessed 1 January 2017).

47 See McMahon, 'Introduction', in Screen Animals Dossier, ed. McMahon, 82.

48 For further discussion of Buñuel's political affiliations, see Ramón Gubern \& Paul Hammond, Luis Buñuel: The Red Years, 1929-1939 (Madison: Univ. of Wisconsin Press, 2012). See also María Soledad Fernández Utrera, 'Buñuel: los años ácratas', in Luis Buñuel: Political Exile, Auteur, Iconoclast, ed. Evans \& Viejo, 607-22 (p. 609).

49 See, for example Akira Mizuta Lippit, Electric Animal: Toward a Rhetoric of Wildlife (Minneapolis/London: Univ. of Minneapolis Press, 2008). Lippit defines a changing relationship between animals and humans from the sacrificial (eighteenth century), to reflective of humanity (nineteenth and twentieth centuries) and then to a role for the contemporary era in which its role is what she describes as spectral and ghostly, representative of a vanished past. Buñuel's work clearly belongs to the first two of these, as the relationship appears to be both sacrificial and reflective. For Pierre Unik's admission that the crew killed the donkey to set up this famous shot, see Agustín Sánchez Vidal et al., 'De Las Hurdes a Tierra sin pan', in 'Las Hurdes': un documental de Luis Buñuel (Badajoz: MEIAC Museo Extremeño e Iberoamericano de Arte Contemporáneo, 1999), 38-75 (p. 45). 
pays to the 'frayed' edges of the human-nonhuman divide. ${ }^{50}$ Kyrou neatly sums up its narrative structure as

[...] based on the phrase 'Yes, but ...', that is to say, Buñuel shows an opening scene that is unbearable, then projects a ray of hope, and ends up by destroying that hope..$^{51}$

Animals play an important role in this conscious destruction of hope, and the co-existence of humans and animals is emphasized from the outset. At just under two minutes, a street shot shows dogs and a long-horned cow emerging from (human) doorways, and at just over two minutes the macabre cockerel beheading sequence discussed earlier begins. Around four minutes later, a shot of a snake writhing over the dry land is accompanied by the narrative voice-over discussing the threat to humans presented by the wolves and wild boar that live near Las Batuecas. Pigs drinking feature in relation to the pollution of the tiny stream that runs through the hamlet of Aceitunilla while, at just under eight minutes, we see a girl scooping up water from this polluted stream to offer it to a baby. Animals, the lack of food and clean water are then linked to the fact that the inhabitants, even in the slightly more fertile valley of Martinandrán, suffer and die. This is the location where a sick girl is said to have remained motionless in the street for days and is later reported, by the narrative voice-over, to have died.

Pigs, we are told, are the only form of meat that is eaten. However we are also told that 'only the so-called rich families own a pig' and that it will be slaughtered once a year and eaten within days. ${ }^{2}$ This leaves the hurdaños at the mercy of the crops they can grow from the infertile soil at the whims of insects and weather. The infamous sequence with the goats is, therefore, designed to illustrate the point that the hurdaños are starving. Goats' milk is 'reserved for the gravely ill' and their meat is only eaten if one dies accidentally - a point cynically illustrated by the infamous abrupt cut to a goat falling to its death (shot, according to Buñuel's son, Juan Luis, by the director himself). ${ }^{53}$ We are also told by the narrator that the "main

50 For a recent account of the persistence of the myths surrounding the inhabitants of Las Hurdes and the symbolic implications of this dead donkey for the Spanish Republic with reference to Picasso's Guernica, see David Matías, 'De las Ordenanzas (1515) de La Alberca a la Tierra sin pan (1933) de Buñuel: breve historia cultural de la dominación de Las Hurdes', in Tuércele el cuello al cisne: las expresiones de la violencia en la literatura hispánica contemporánea (siglos XX y XXI), ed. Cristóbal José Álvarez López et al. (Sevilla: Renacimiento, 2016), 165-76 (pp. 171-73).

51 Kyrou, Luis Buñuel, trans. Foulke, 43.

52 See Buñuel et al., Reverse Angle, ed. Davies \& Rodríguez, 20.

53 Kyrou points out that the puff of smoke revealing the goat was shot did not appear in the copy available at MOMA and that, when asked about this, Buñuel 
food industry is bee-keeping', yet (in a fine example of Kyrou's 'yes but-no but' narrative aesthetic) this information is immediately qualified by the information that the owners of these bees live in La Alberca rather than in the poorer villages of Las Hurdes, and that the hives are only brought to the region in winter at great risk to the men and mules that bring them.

This factual mention of the hives is aesthetically overloaded with the gratuitous and entirely 'crew-constructed' shot of a dead donkey we are led to believe has been killed by bees (but that has, like the goat, been sacrificed by members of the film crew). Providing yet more semantic overload, the voice-over then claims that one month before the arrival of the film crew, three men and eleven mules were killed in similar incidents. Animal rights are as irrelevant to this documentary as the rights of the impoverished hurdaños are to the owners of the bee-hives, and towards the end of the film, this life/death human-nonhuman symbiosis is highlighted in the sequence about compost. According to the narrator, there are so few animals that in order to enrich the infertile earth the inhabitants must collect leaves from the mountains. These they then sleep on these for a few months, before using them as animal bedding that will, in turn, be used to fertilize the crops. However, to offset the positive implications of this useful human-animal exchange one of the men collecting the leaves is bitten by a viper.

In summer, we discover from an aesthetically jarring sequence featuring a measuring bowl and close-up diagrams, the Anopheles mosquito spreads the malaria from which all the hurdaños suffer. The reason for this this abruptly scientific sequence is then clarified by its juxtaposition with shots of a (supposedly) dead baby girl that emphasize the futility of human scientific knowledge in the face of such extreme rural poverty. ${ }^{54}$ Finally, the narrative returns to the living arrangements of the 'hurdanos'. These tend to have only one room, although the better-off will have a stable on the lower storey. In this context, to be 'rich' means to live in closer contact with animals, providing access to the animal food chain and to the more nutritious compost produced from the bedding shared by the human and nonhuman occupants of these more prestigious dwellings: at which point this simultaneously surreal and factual account of the frayed edges of

claimed it was unimportant. The same footnote on this page also mentions that, according to Juan Luis, Buñuel shot the goat himself (Kyrou, Luis Buñuel, trans. Foulke, 42).

54 Kyrou discusses the aesthetically jarring inclusion of this scientific description of the anopheles mosquitos as 'a very brief classic documentary [...] its didactic quality transforming the sequence into an expression of the grotesque' (Kyrou, Luis Buñuel, trans. Foulke, 45). 
human-nonhuman symbiosis is brought to a close with the image of an old woman tolling the inevitability of death. ${ }^{55}$

\section{Conclusion: 'nos diferenciamos poco'}

Black humour and parody systematically overload these images of nonhuman-human interaction in Buñuel's films: '[n]os diferenciamos poco' is the devilish comment that Silvia Pinal's character makes to the would-be saint Simón in Simón del desierto, and the same conclusion might be drawn from human-animal interaction in these films. Actively associated with leftwing politics and communism prior to the Civil War in which three of his close friends, Juan Piqueras, Ramón Acín and Lorca, were assassinated, these early films exemplify the use of on-screen animal imagery to raise questions about the violence of human politics, to rupture the visual field of the gaze, to breach overly simplistic notions of individual human subjectivity and to fray the edges of the human-nonhuman divide.

Having read Freud, Buñuel is aware that our 'others' reside both separately from and within our own unconscious thought processes, not unlike the hare in the paté in La Voie lactée. These on-screen animal references play a vital role in the representation of blended human-animal subjectivity. They remind us that it is important to look back at animals and that is it salutary to be ashamed of the limits of our own perception; to laugh at the absurdity of our own convictions; and to remember that we, like the human and nonhuman protagonists of these films, are the product of an on-going process of social, cultural and political reconstruction. The animals in these early films may also explain why we have returned to consider our 'animal' reflections so seriously again, nearly a century on, and at this distinct yet similar time of economic crisis accompanied by extreme ideological divisions and the rise of the political right. At such times it is useful to turn a blackly humorous pseudo-scientific gaze on our own limitations and Un Chien andalou reminds us of our propensity towards oedipal resentment, our sexual slipperiness and our closeness to an abject that is conjured up in the dead donkeys and the severed calf's eye. L'Âge d'or warns us to beware our sacred cultural cows and the hypocritical division we make between our 'animal' passion and our social facade, while Las Hurdes reminds us of the intimate human-animal relationship that supermarkets and virtual reality cannot entirely erase, while its sardonic narrative voice-over (like the old woman at the end of the film) drones an

55 For a detailed examination of the link between death and animals on screen, see Jonathan Burt, 'Morbidity and Vitalism: Derrida, Bergson, Deleuze, and Animal Film Imagery', Configurations, 14:1-2 (2006), 157-79. 
alert to the folly of assuming we have any "preponderancia sobre el [elemento] natural'.*

* Disclosure Statement: No potential conflict of interest was reported by the author. 